\title{
INSTITUCIONES DE DERECHO CIVIL
}

Lodovico Barassi ${ }^{I}$

\section{LA DECLARACIÓN Y LA VOLUNTAD EN LOS NEGOCIOS}

Para que exista un negocio jurídico se requiere como mínimo una voluntad declarada. Examinaremos en primer lugar el elemento "declaración" y después (en el n. sig.) la voluntad.

DECLARACIÓN. Es la manifestación exterior de la voluntad. Tiene por objeto la constatación del querer interno, o sea. en esencia, la constatación del negocio jurídico que crea o extingue una relación jurídica.

Como principio general rige la libertad de formas. Pero en algunos casos la ley impone una forma determinada: forma constitutiva (como veremos en los nn. 275 y ss.).

LIBERTAD DE FORMAS. Por regla general una declaración de voluntad puede exteriorizarse en cualquier forma (oral, escrita, etc.) apta para expresar tal voluntad.

Respecto al grado de exteriorización necesario para la eficacia de una declaración de voluntad la ley establece un límite mínimo con arreglo al cual basta aquella forma que permita reconocer externamente el querer interno, de modo que sea suficiente para su constatación. Se requiere, pues que la declaración haya adquirido autonomía, es decir, se haya independizado de su autor.

[A primera vista el artículo 54 de nuestro Código Civil de Comercio está en contradicción con este principio; sin embargo, no cabe la menor duda cpie si después de contestada la carta el propio aceptante la rasga, por ejemplo, antes de remitirla al

Profesor de la Universidad Católica del Sacro Cuore de Milán

Traducción y notas de comparación al Derecho español por RAMON GARCIA DE HARO DE GOYTISOLO. Ayudante de Cátedra de Derecho Ci\ il de la Universidad de Barcelona. Con colaboración de MARIO FALCÓN CARRERAS. Secretario del Instituto de Derecho Comparado de Barcelona. Seminario de Derecho. 1995.

3 Messineo. Manuale. Cil. Sobre las declaraciones recepticias y no recepticias. V.: Barrassi. La natalienzone neccesaria nelle dichiarazionin stranindiziali. Milán. 1926 - De la voluntad como elemento esencial del negocio jurídico: Pugliatti. En Ric. Dir. Comm.. 1910. 1. 241 sig. - Carola Ferrara en Annuarie di dir. Compar., ele.. XV. N. 4. -

Acerca de las declaraciones de voluntad a través de su actuación: Fada y. Densa. Note allePand. Di Windscheid. 1. P. 800: Chavol. Propritémobilieré. 11. 347-348. - Sobre las declaraciones expresas y tácitas y respecto al silencio: Barassi, La teoriagener. Di obligaz., cil., 11. N. 121 sla 
correo, o haberle ciado de cualquiera otra forma una autonomía, no existirá contrato, porque fallará en realidad la "declaración " de voluntad, "Contestar aceptando " significa emitir una declaración de voluntad que adquiere autonomía, y no simplemente redactar una carta. Además, si no ha adquirido autonomía, no podrá probarse su emisión, que es siempre el requisito mínimo (cfr. En efecto S. T. S. de 26 de enero de $1926)$.

Adviértase que hacemos esta afirmación con entera independencia de la naturaleza receptivita o no de la declaración de voluntad y del momento en que la misma o el contrato deban de estimarse perfeccionados. Cfr. Más adelante]

No basta escribir una carta en la que se contenga una declaración de voluntad; es preciso, además, que ésta haya sido expedida. [En nuestro Derecho. Pese a lo que pudiera deducirse del tenor literal del articulo 54 del Código de comercio, es indudable que siempre será requisito mínimo para la existencia de una declaración de voluntad (prescindimos de los requisitos que exigirá en cada caso su perfección o la del contrato) la independización de la misma (ver nota precedente), que no siempre presupone necesariamente la expedición de la carta].

No se aplicará, sin embargo, esta regla, cuando de la misma pudiera derivarse un gran perjuicio para la razonable buena fe de los terceros. Por ello, cuando una declaración escrita esté destinada al tráfico jurídico (por ejemplo, títulos de crédito: nn. 231 y ss.) aunque se hubiere puesto en circulación sin conocimiento del deudor o del emitente puede ser válida por la necesidad de proteger la buena fe de los terceros. Así resulta de la totalidad del sistema de nuestro Derecho privado. [Esta excepción, igualmente aplicable en Derecho español, se refiere no a la necesidad de independización, sino a la exigencia de expedición voluntaria].

La ley cuenta con el buen sentido de los declarantes, que procurarán exteriorizar su voluntad de modo que llegue fácilmente a conocimiento de los demás interesados y no resulte en la práctica letra muerta. Queda de todos modos el peligro de que tal posibilidad se realice. Por ello, para prevenir los inconvenientes prácticos que se derivarían, la ley puede:

Exigir que la exteriorización de una voluntad consista precisamente en la actuación externa de la misma. Así ocurre respecto a la ocupación y el abandono (nn. 164 y 171). A veces son los propios interesados quienes eligen esta forma (actuación) de declarar su voluntad, que tiene la ventaja de anticipar los efectos de la declaración:

Así, el Código Civil (art. 1327) establece que cuando el oferente solicite la ejecución inmediata del contrato y además no resulte ni de la oferta ni de los usos generales la exigencia de una previa contestación de aceptación, se considera perfeccionado el contrato "en cuanto la otra parte haya iniciado su ejecución"; el contrato se perfecciona, pues, en el momento de la aceptación, que el aceptante viene a realizar, por así decirlo, en forma plástica y sin comunicarla directamente al oferente (cfr., también, art. 1444, ap. $2 .^{\circ}$ ). En todos estos casos la voluntad no se comunica a los interesados, pero se manifiesta externamente a través de su realización. [Igualmente admisible en nuestro Derecho, pese a la inexistencia de un artículo análogo al 1327 del C. C. italiano]

Aunque esta forma de declarar la voluntad por medio de su actuación exterior tenga aparentemente una gran fuerza, puede dejar, sin embargo, ciertas dudas acerca de la voluntad efectiva, cuando (especialmente en la ocupación o el abandono) el acto externo pueda manifestar también una voluntad distinta. Así es perfectamente 
posible que el cese en la posesión de una cosa mueble se deba simplemente a un extravío (cfr., por ejemplo, art. 1257). En tal caso se aplicará también el principio según el cual la verdadera voluntad (del que abandonó la cosa) no puede inducirse de ciertos criterios exteriores a la persona (por ejemplo, el valor de la cosa, o el lugar en que fue hallada); en la duda el animus derelinquendi no puede presumirse (FADDA y BENSA; en contra CHAROT).

Exigir una forma escrita constitutiva. Sobre esta hipótesis, vides más adelante

Subordinar la exigibilidad (v. g. en el testamento secreto) aI depósito ante notario (n. 117) [sin correspondencia en Derecho español]-,

Disponer que una declaración de voluntad no produzca efectos jurídicos -es decir, no se perfeccione- en tanto no se haya comunicado (notificado) a la persona o personas que tengan interés en conocerla: declaración de voluntad receptivita (v.g. las declaraciones del contrato). Hay que tener en cuenta que estas declaraciones pueden dirigirse a un número indeterminado de personas, es decir, al público; por ejemplo, promesa al público (vid.n. 191). Por regla general las declaraciones al público se consideran perfeccionadas desde el momento de la recepción.

MOMENTO EN QUE SE PERFECCIONA LA DECLARACIÓN RECEPTICIA.- EI Código en principio se mantiene fiel a la regla de que el momento de la perfección de una declaración de voluntad recetica es el de su "recepción" por el destinatario. Este tipo de declaración pasa por tres fases distintas: 1) la declaración sale de la esfera de disponibilidad del declarante, es decir, se hace autónoma: momento de la declaración (por ejemplo, la carta del remitente se hecha al buzón); 2) la declaración entra a la esfera de disponibilidad del que la ha de recibir: recepción (v.g., la carta de aceptación, se introduce en el buzón de la casa del destinatario, es decir, del oferente; 3) El destinatario de la declaración entra en conocimiento del contenido de la declaración. Ahora bien, como la fase que puede constatarse exteriormente con facilidad es la segunda y no la tercera, se presume normalmente el conocimiento cuando exista la recepción. Así lo establece el Código (art. 1335) respecto a la formación del acuerdo contractual, refiriéndose en particular a la oferta, la aceptación y su renovación ( $\mathrm{n}$. 192); pero en realidad es aplicable a cualquier declaración dirigida una persona determinada, sin embargo, en el fondo es siempre el tercer momento (la percepción) el que agota conceptualmente el proceso de la notificación (Barassi); en efecto, el destinatario puede probar que sin culpa suya se encontraba en imposibilidad de conocer la declaración (art. citado).

[Nuestro Código Civil estima como momento de Ia perfección de una declaración de voluntad recepticia el de su conocimiento por el destinatario (art. 1262. ap. 2. ${ }^{\circ}$ ). Sinembaigo, esto ha de entenderse a salvo que medie mala fe del quien recibió la carta, pues la ley no puede nunca servir de protección a la mala fe. La declaración deberá estimarse perfeccionada en tal caso en el momento en el que pudo tener conocimiento de ello. El Código de comercio establece (art. 54) que "los contratos por correspondencia quedarán perfeccionados, desde que se conteste aceptando la propuesta". Acerca de Ia interpretación de este precepto, que en nada contradice la necesidad de conocimiento del destinatario para la perfección de las declaraciones receptorías, véase más adelante nota a Ia revocación de las declaraciones de voluntad]. 
NOTIFICACIONES PÚBLICAS Y PUBLICIDAD.- Las notificaciones públicas se perfeccionan en el momento que adquieren publicidad (por ejemplo, inscripción el registro, fijación de la notificación en un lugar público, etc.), es decir, en el momento de la recepción. En efecto, el registro está a disposición del público y con ella la transcripción $(,, .258)$ es ya perfecta, sin que el interesado, el destinatario, pueda oponer que, sin mediar culpa por su parte, no consultó el registro. Por tanto, el artículo $1335^{4}$, como aclara la propia ley. se aplica solo a las declaraciones dirigidas a persona o personas determinadas. Cfr. n. 257 bis, A, a.

La notificación de una declaración recepticia puede hacerse por cualquier medio; oralmente o por escrito; por correo o a través de un mensajero, que puede serlo de ambas partes contratantes; o también a través de un oficial público, como a veces exige la ley para dar mayor seguridad a la constatación.

LAS DECLARACIONES NO RECEPTICIAS. En cambio, son eficaces, aun sin que la declaración se dirija al interesado, desde el momento en que adquiera aquel mínimo de exteriorización autónoma antes señalado. Este tipo de declaraciones tiene menor importancia práctica y. además, en los raros casos a que tiendan a modificar el estado patrimonial de una persona, la ley toma ciertas medidas preventivas para su protección (por ejemplo, la declaración testamentaria, no recepticia, no produce la adquisición de la herencia - sí. en cambio, de! legado hasta que el heredero haya aceptado).

Por tanto, en las declaraciones receptorías la notificación al interesado es elemento constitutivo ( $y$, por lo tanto, imprescindible) del negocio jurídico contrariamente a lo que ocurre en las declaraciones no receptorías. Es decir, la notificación de una declaración de voluntad no recepticia no será nunca elemento constitutivo del negocio jurídico en el que eventualmente intervenga, sino simplemente la notificación de una declaración de voluntad ya anteriormente eficaz, sí antes de la notificación se hubiere exteriorizado suficientemente (n. 50).

REVOCACIÓN DE LA DECLARACIÓN.- Mientras una declaración de voluntad no se haya perfeccionado puede revocarse siempre. $Y$ ello es cierto, tanto para las declaraciones no receptorías (ya lo veremos en particular respecto al testamento: $n$. 136), como para las receptorías. En especial por lo que se refiere a estas últimas, su autor puede impedir por cualquier medio que llegue a producirse la notificación o por lo menos hacer que la revocación llegue al destinatario antes de la declaración (por ejemplo, art. 1328, n. 192). [Aunque nuestro Derecho no lo establezca expresamente, es evidente que deberá aplicarse la misma solución. En nada se opone ello al artículo 54 del Código de comercio, ya que, una de dos, o este articulo significa solamente que el contrato se perfecciona en el momento de cognición de la carta (y entonces cabe revocación), si bien sus efectos se retrotraen al momento de la aceptación, o en otro caso si se estima que el contrato se perfecciona realmente desde la omisión, se tratará en definitiva de una declaración de voluntad no recepticia.

Téngase en cuenta que esta cuestión (posibilidad de revocación de una declaración de voluntad recepticia antes de su perfección, es decir, antes de la recepción) nada tiene que ver con el problema de la fuerza vinculante de una declaración de voluntad unilateral (v. g. de la oferta) que presupone precisamente su perfección (el hecho de haber llegado a conocimiento del destinatario: vide nota a 192). ]

$4 \quad$ [Dice textualmente dicho artículo: "La propuesta, la aceptación así como su revocación, en general. cualquier declaración dirigida a una persona determinada, se reputan conocidas-desde el momento de su llegada a la dirección del destinatario, si éste no prueba que, sin culpa suya, se hallaba en imposibilidad de conocerlas".] 
DECLARACIÓN EXPRESA Y DECLARACIÓN TÁCITA. - Atendiendo al distinto grado de constatación del querer interno que resulte de la conducta del declarante, la declaración puede ser directa (expresa) o indirecta (tácita).

a) La declaración es directa o expresa cuando la voluntad se manifiesta en una forma que de acuerdo con el uso común o con el uso particular del declarante, está destinada a expresar exacta y primordialmente la voluntad que el declarante quiere expresar. En la práctica es el caso más frecuente (quiero adquirir una mercancía y expreso al vendedor la voluntad de adquirirla).

b) La voluntad indirecta o tácita de manifiesta, en cambio, a través de una conducta que, si bien se dirige primordialmente a expresar una determinada voluntad, está, sin embargo, en tan íntima correlación con otra voluntad del mismo, que esta última se deduce por necesidad lógica de la primera, pues una voluntad en contrario sería incompatible con la que quiso primordialmente manifestar (art. 1457, en el caso antes contemplado, si digo al vendedor que me remita la mercancía, esta voluntad es incompatible con la de no comprar). Véase también respecto a la aceptación tácita de la herencia el art. 476.

Como según acabamos de ver, en las declaraciones de voluntad indirectas (tácitas), resulta más difícil deducir de la conducta externa del declarante una determinada voluntad, la ley no admite esta forma indirecta en los casos que, por su importancia, quiere evitar cualquier posibilidad de duda (por ejemplo, art. 1273, ap. $2^{\circ}$.) [Igualmente en Derecho español, v. g., art. $7 H 3$, ap. $7^{\circ}$.]

Adviértase que la prohibición de presumir una determinada voluntad no implica la exclusión de la forma indirecta, sino simplemente que en la duda (lo cual es distinto: presupone falta de claridad) no pudo apreciarse tal voluntad, es decir, solo será admisible la declaración en forma indirecta.

EL SILENCIO.- Una forma de declaración bastante dudosa por lo que respecta a su valor como medio de constatación es el "silencio". No cabe duda de que el silencio podrá valer como declaración de voluntad, siempre que los terceros destinatarios de la declaración puedan interpretarlo razonablemente como manifestación de una determinada voluntad.

En la práctica es posible que así ocurra respecto a la aceptación de una oferta de contrato, a condición de que las circunstancias conocidas por los terceros (y en especial por el oferente) permitan cualificar claramente el silencio como aceptación. De todas maneras estos casos deben admitirse con mucha prudencia. A veces es la propia ley quien impone esta valoración del silencio, como cuando ocurre cuando la oferta se dirige a la formación de un contrato del que sólo nazcan obligaciones para el proponente (art. 133).

Se trata, no obstante, de una materia muy discutida, así algunos creen que por declaración de voluntad hay que entender siempre un conjunto de signos exteriores positivos y que no es cierto, por tanto, que "quien calla otorga", sino que por la negativa, exceptúa los casos en el que calla estuviere obligado a hablar por voluntad de la ley, o del juez, o como consecuencia de un contrato.

[Respecto a! silencio como declaración de voluntad en nuestro Derecho, vide S. T. S. de 24 de noviembre 1943, según la cual el silencio puede considerarse como 
asentimiento, siempre que el que calle "pueda contradecir "y "tuviere obligación a contestar, o cuando menos, fuere natural y normal que manifestare su disentimiento, si no quería aprobar los hechos o propuestas de la otra parte ". Como casos concretos recogidos en el Código, vide arts. 364, ap. $2 . \quad 898,1005,1556$; vide, también, art. 7 del Código de comercio.]

VOLUNTAD.- El elemento central del negocio jurídico, aquél que determina la producción (se entiende, en virtud de la ley) de los efectos jurídicos, es la voluntad.

AUTONOMÍA INDIVIDUAL.- La importancia de la voluntad, que es el elemento fundamental de todo negocio jurídico, resalta aún más en un sistema de Derecho privado que, como el nuestro, se funda en el principio de "autonomía individual", es decir, en la facultad concedida al individuo de regular por sí. y según su propia voluntad. sus propios asuntos, actuando con ello su interés personal en el marco del interés colectivo, con el que debe armonizarse.

Se ha puesto en duda si la voluntad es o no elemento esencial del negocio jurídico, ya que algunas veces es suficiente su apariencia (incluso faltando realmente la voluntad: Cfr. n. 49).

Si por "esencial" se entiende la exclusión de toda excepción, la respuesta ha de ser negativa. Pero como tales excepciones son. por regla general, casos patológicos, o de protección a la buena fe de los terceros ( $y$, por tanto, no excluyen la importancia normalmente fundamental de la voluntad), en definitiva, la teoría del negocio jurídico no pierde en modo alguno su valor.

PRESUPUESTOS DE LA AUTONOMÍA DE LA VOLUNTAD INDIVIDUADLO que llevamos dicho demuestra ya que el ordenamiento jurídico no se presta a actuar sin más cualquier querer que manifieste, aun en forma legalmente correcta, una persona. El principio de la autonomía -prescindiendo de que. en la actualidad, pueda servir para actuar en interés colectivo además del privado (n. 152)-presupone ante todo que el individuo sea capaz de usar bien de ella.

De aquí un doble orden de limitaciones: las que se refieren a la capacidad o la causa, dirigidas a salvaguardar la seriedad de la voluntad en interés del individuo (y también de la sociedad, que podría resultar perturbada por las decisiones de una voluntad no madura o poco seria); y en segundo lugar, las que tienden a limitar al individuo en protección, principalmente, de un interés social.

Respecto a este segundo grupo bastará con recordar aquí que son limitaciones dirigidas a proteger el orden público o las buenas costumbres (cfr. art. 31, disposiciones sobre la ley en general y at. 1343). [En cuanto a nuestro Derecho cfr. artículos 4, ap.

2. $\quad$; 1255.1271 . ap. $3^{\circ}$, y 1275 del C. C.j La normas que establecen estas limitaciones son categorías, no dispositivas. Téngase en cuenta que el orden público es una expresión elástica que debe entenderse de acuerdo con las circunstancias y el ambiente del tiempo en que se haga la interpretación (en la actualidad, de acuerdo con las exigencias colectivas, cuya prioridad de protección resulta de un conjunto de leyes de Derecho público y privado, que el intérprete, aun de Derecho privado, no puede olvidar).

Algunas limitaciones entran en ambas categorías: por ejemplo, la necesidad de forma escrita (o solemne) para ciertos negocios jurídicos (n. 257). 